\title{
Postharvest Management Practices of Grains in the Eastern Region of Kenya
}

\author{
Anastasia W. Njoroge ${ }^{1}$, Ibrahim Baoua ${ }^{2}$ \& Dieudonne Baributsa ${ }^{1}$ \\ ${ }^{1}$ Department of Entomology, Purdue University, Indiana, USA \\ ${ }^{2}$ Department of Entomology, Université de Maradi, Maradi, Niger \\ Correspondence: Dieudonne Baributsa, Department of Entomology, Purdue University, 901 W. State Street, \\ West Lafayette, IN 47907, USA. Tel: 1-765-494-8713. E-mail: dbaribut@purdue.edu
}

\author{
Received: October 22, $2018 \quad$ Accepted: December 17, $2018 \quad$ Online Published: February 15, 2019 \\ doi:10.5539/jas.v11n3p33 \\ URL: https://doi.org/10.5539/jas.v11n3p33
}

The research is supported by Purdue University through the PICS3 project funded by the Bill and Melinda Gates Foundation.

\begin{abstract}
Cereals and legumes play a major role in the production systems and diets of farmers in the semi-arid eastern region of Kenya. Efficient postharvest management can tremendously contribute to food security in these regions. A study was carried out in three counties in eastern Kenya to assess pre and postharvest management practices among farmers. Data was collected using semi-structured questionnaires designed and administered using Kobo Toolbox via android tablets. Results showed that farmers cultivated three main crops: maize (98\%), beans 66\%), and pigeon peas $(28 \%)$. The most saved seed crops were beans $(80 \%)$ and pigeon peas $(50 \%)$. Majority of the farmers $(80 \%)$ experienced pre-drying losses due to insects $(48 \%)$, rodents $(40 \%)$ and birds $(39 \%)$. Farmers stored grain for consumption (80\%) and for sale (19\%). About $48 \%$ of farmers stored the grain for more than 9 months. Challenges during grain storage were insects $(57 \%)$ and rodents $(43 \%)$. Primary methods of grain preservation included hermetic methods $(61 \%)$ followed by insecticides $(33 \%)$. While progress is being made in addressing storage challenges, there still a need to continue building awareness about improved storage technologies and find solutions for pest infestations in the field and drying after harvest.
\end{abstract}

Keywords: storage, drying, grain, hermetic methods, semi-arid

\section{Introduction}

Cereals and legumes are the most important food staples in Sub-Saharan Africa (Abate et al., 2012; Macauley \& Ramadjita, 2015). They are often grown alone or in intercropping systems (Van Duivenbooden et al., 2000). Up to $90 \%$ of agricultural production in East Africa is dominated by smallholder farmers and about $75 \%$ of Kenyans owe their livelihood to agriculture (FARA, 2006; Stathers et al., 2013; Wiggins \& Keats, 2013). Smallholder agriculture is often faced with low productivity due to inefficient production systems.

Most grain in Kenya is produced in the Rift Valley, Western, Nyanza, Central and Eastern regions (Rao et al., 2015). Eastern Kenya produces cereal and legume crops including maize (Zea mays L.), beans (Phaseolus vulgaris L.), green grams (Vigna radiata L.), pigeon peas (Cajanus cajan L.), millets (Pennisetum spps), sorghum (Sorghum bicolor L.), cowpea (Vigna uncguiculata L.) and dolichos lablab (Lablab purpureus L.) to ensure self-sufficiency in the face of climate change (Mergeai et al., 2001; Kimiti et al., 2009; Muhammad et al., 2010; County et al., 2016). The demand for staple crops such as maize is expected to continue to grow despite the diversification of Kenyan diets. Like all farmers in Sub-Saharan Africa (SSA), farmers in Kenya face many challenges during crop production including widespread changes in rainfall and temperature patterns. Changes in weather patterns threaten agricultural production and increase the vulnerability of people who depend on agriculture for their livelihoods (Speranza et al., 2008; Tabu et al., 2013).

In Kenya, grain production and national consumption patterns do not tally. This is common, especially for maize, as it does not meet national demand (Gitonga et al., 2013). Often, the deficit is met by imports or food aid. In addition, demand for maize in the processing of animal feeds is also expected to increase due to a recent major investment in the subsector (Gitonga, 2017). Annually, Kenya produces up to 3.6 million MT of maize while it 
imports up to 1.5 million MT in some years to meet its food demand (FAO, 2014). With postharvest losses estimated at 30\% (Mutambuki \& Ngatia, 2006), Kenya loses about half a million MT each year. Efforts to mitigate postharvest losses have the potential to reduce or eliminate maize imports into Kenya. Improved postharvest management can increase food supply without the need to use additional resources such as land, water, seed and fertilizer.

Crop losses occur before and after harvest and include inadequate drying, inefficient storage facilities, and lack of appropriate technologies. Drying is done in the field and at home while storage is done in or near the house using different containers and technologies. Storage is often plagued by a myriad of problems such as insects, mold, birds, rodents and animals. Therefore, it is important to understand farmers' pre and postharvest management practices of key important cereal and legume grains in the semi-arid region of Eastern Kenya to improve food security and income of farm households.

\section{Methodology}

\subsection{Study Area}

This study was conducted in three counties (Tharaka Nithi, Makueni and Machakos) in the Eastern region of Kenya (Fig. 1). The survey was implemented from October 9 to November 3, 2017 targeting farmers who had harvested and stored grain from the previous major (long rainy) season. The Eastern region is mainly semi-arid with low and erratic rainfall that results in periods of severe drought. This area is prone to government hunger and poverty interventions. The region has bimodal rainfall characterized by a long rainy season from MarchMay and short rainy season between September and December (Jaetzold et al., 2006).

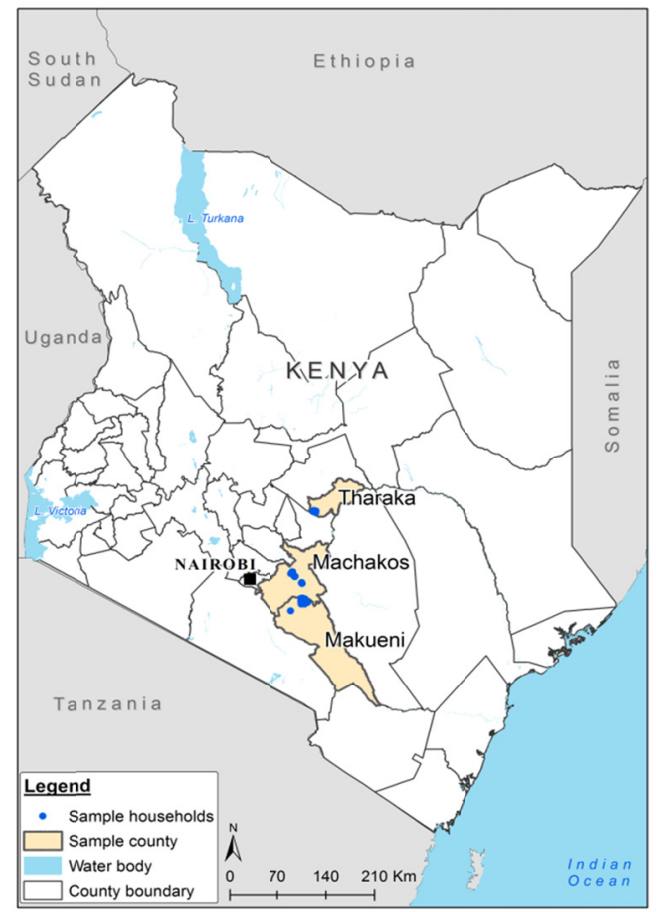

Figure 1. Map of Kenya showing the study sites (in blue dots) in three counties in Eastern Kenya

Source: Data collected during the study and mapped using QGIS software.

\subsection{Sampling, Data Collection and Analysis}

We purposively selected 50 villages in the three counties (16 villages in Tharaka-Nithi, 17 villages in Makueni, and 17 villages in Machakos). The number of villages per country was determined based on cereal and legume production. We targeted to interview 13 farmers randomly selected in each village. We were able to survey a total of 613 farmers $(94.3 \%$ of our goal). The selected farmers were interviewed using a semi-structured questionnaire with open and close-ended questions. Questions included qualitative and quantitative data focused on the socio-economic characteristics of the respondents; major cereal and legume crops produced, the quantity produced; seed sources and storage, grain drying before and after harvest, storage practices; farmers' knowledge 
of the causes of postharvest losses and loss prevention measures. The questionnaire was uploaded to Kobo Toolbox, deployed and administered via handheld devices (android tablets). Five enumerators collected data and received consent from individual farmers before each interview. Data collected were coded and analyzed using the SPSS 24.0 (IBM Corp., 2016, New York, NY, United States). Cross-tabulation tables were constructed, and descriptive analyses done to summarize the data.

\section{Results}

\subsection{Characteristics of the Respondents}

Table 1 summarizes the characteristics of the respondents. Among the respondents: $64 \%$ were female, $87 \%$ were married, $49 \%$ were above 50 years of age, and $57 \%$ had more than a high school education. The average household size was five members. About $82 \%$ of the respondents had 10 years or more of experience in their main activity. Most respondents (85\%) were smallholder farmers owning less than 5 acres of land.

Table 1. Characteristics of respondents and their socio-economic attributes $(\%)$ in the three counties surveyed in Eastern Kenya

\begin{tabular}{|c|c|c|c|c|}
\hline \multirow{2}{*}{ Variable } & \multicolumn{3}{|c|}{ \% Respondents } & \multirow{2}{*}{ Overall $(n=613)$} \\
\hline & Tharaka-Nithi $(\mathrm{n}=170)$ & Makueni $(n=216)$ & Machakos (n=227) & \\
\hline \multicolumn{5}{|l|}{ Gender } \\
\hline Female & 15.3 & 23.2 & 25.9 & 64.4 \\
\hline Male & 12.4 & 12.1 & 11.1 & 35.6 \\
\hline \multicolumn{5}{|l|}{ Age } \\
\hline $18-30$ & 2.4 & 2.9 & 3.3 & 8.6 \\
\hline $31-40$ & 5.9 & 5.7 & 6.9 & 18.4 \\
\hline $41-50$ & 7.0 & 8.5 & 8.5 & 24.0 \\
\hline over 50 & 12.4 & 18.1 & 18.4 & 48.9 \\
\hline \multicolumn{5}{|l|}{ Marital status } \\
\hline Single & 1.8 & 1.3 & 1.0 & 4.1 \\
\hline Married & 24.0 & 30.5 & 32.6 & 87.1 \\
\hline Widowed & 1.5 & 3.3 & 2.9 & 7.7 \\
\hline Separated/divorced & 0.5 & 0.2 & 0.5 & 1.1 \\
\hline \multicolumn{5}{|l|}{ Education level } \\
\hline None & 0.3 & 1.0 & 0.5 & 1.8 \\
\hline Basic Literacy & 2.1 & 1.6 & 1.8 & 5.5 \\
\hline Primary School & 9.5 & 12.2 & 13.9 & 35.6 \\
\hline High School & 10.6 & 12.2 & 13.5 & 36.4 \\
\hline Tertiary/University & 5.3 & 8.1 & 7.3 & 20.7 \\
\hline \multicolumn{5}{|l|}{ Main activity } \\
\hline Full-time employee & 8.2 & 3.7 & 4.8 & 5.4 \\
\hline Business & 7.1 & 10.2 & 11.5 & 9.8 \\
\hline Agriculture & 82.4 & 86.1 & 82.4 & 83.7 \\
\hline \multicolumn{5}{|l|}{ Years in activity } \\
\hline Less than 5 & 75.9 & 87.5 & 81.1 & 81.9 \\
\hline $5-10$ & 17.1 & 8.8 & 13.2 & 12.7 \\
\hline More than 10 & 7.1 & 3.7 & 5.7 & 5.4 \\
\hline \multicolumn{5}{|l|}{ Land size (acres) } \\
\hline $0-1$ & 9.3 & 6.2 & 5.7 & 21.2 \\
\hline $1-5$ & 16.2 & 21.4 & 26.3 & 63.8 \\
\hline $5-10$ & 1.5 & 4.9 & 3.8 & 10.1 \\
\hline More than 10 & 0.8 & 2.8 & 1.3 & 4.9 \\
\hline
\end{tabular}

\subsection{Main Cereal and Legume Crops Cultivated}

Table 2 provides details of the first three main crops grown by respondents. Overall across the three counties, the main food crops were maize (98\%), common beans (66\%) and pigeon peas (28\%). Respondents in Tharaka-Nithi county predominantly farmed two main crops (cereal and a legume), while those in Makueni and Machakos 
counties grew three main crops. Majority of the respondents (69\%) said the main reason for growing cereal and legume grains was for both sale and consumption.

Table 2. Main cereal and legume crops cultivated by farmers in three counties in Eastern Kenya

\begin{tabular}{lllllll}
\hline \multirow{2}{*}{ Crop } & \multicolumn{5}{c}{ \% Respondents } \\
\cline { 2 - 7 } & Maize & Beans & Pigeon pea & Cowpea & Green gram & None \\
\hline First main crop & 98.0 & - & - & - & - & - \\
Second main crop & - & 66.7 & 20.7 & 6.0 & 3.4 & - \\
Third main crop & - & 18.4 & 28.4 & 11.4 & 6.9 & 34.8 \\
\hline
\end{tabular}

\subsection{Drying Practices}

Table 3 summarizes farmers drying practices. Farmers pre-dried their crops in the field. Eighty percent (80\%) of farmers experienced postharvest losses during the pre-drying period. The main causes for these losses were insects $(48 \%)$ followed by rodents $(40 \%)$ and birds $(39 \%)$. All respondents reported having challenges during drying of grain prior to storage. A little over half of farmers (55\%) mentioned rain as the main challenge during the drying period. Majority of the respondents (98\%) mentioned drying in the sun as the most commonly used method for reducing grain moisture content to acceptable levels before storage. About two third of the respondents $(65.4 \%)$ dried on the ground while $21.7 \%$ used a mat/tarpaulin for drying.

Table 3. Summary of pre-drying losses, grain drying practices and challenges to farmers in three counties in Eastern Kenya

\begin{tabular}{ll}
\hline Variable & \% Respondents \\
\hline Pre-drying losses & 28.7 \\
Mold & 27.4 \\
Animals & 12.9 \\
Theft & 39.2 \\
Rodents & 40.1 \\
Birds & 48.0 \\
Insects & \\
\hline Drying systems & 21.4 \\
Field & 2.3 \\
Shade & 97.7 \\
Sun & 3.3 \\
Smoking & 3.9 \\
House & 65.4 \\
\hline Drying surfaces & 21.7 \\
Ground & 10.6 \\
Mat/Tarpauline & \\
Others & 53.5 \\
\hline Drying challenges & 17.9 \\
Rain & 13.7 \\
Drying space & \\
Contamination &
\end{tabular}

\subsection{Storage Practices}

Tables 4, 5 and 6 provide summaries of crop storage practices. Maize was the most produced and stored crop followed by common beans (Table 4). Across the three counties, the main reason to store was home consumption $(80 \%)$ followed by income security $(19 \%)$. Most farmers $(73.9 \%)$ stored for 6 months or more (Table 5). The primary method of grain protection was hermetic methods $(61 \%)$ followed by chemical pesticides (33\%). A little over half of the farmers $(55.6 \%)$ store their harvested grain in a room in the house. Insect damage was the biggest challenge during grain storage (57\%) followed by rodent damage (43\%) (Table 6). Most farmers dealt with these challenges by turning to new storage technologies $(46 \%)$. A good number (54\%) did not use 
chemicals. The main reason was because chemicals are toxic/harmful to their health (56\%). Majority of the farmers saved grains as seed from the previous harvest for replanting in the next season (Table 7). But the quantity saved varied from one crop to another- $80 \%$ for common beans, $50 \%$ for pigeon peas and $20 \%$ for maize. Though farmers saved seed, $86 \%$ also mentioned buying seed from agrodealers' shops.

Table 4. Summary of first three major stored crops grown, and quantity produced and stored by farmers in three counties in Eastern Kenya

\begin{tabular}{|c|c|c|c|c|c|c|c|}
\hline \multirow{2}{*}{3 major crops } & \multirow{2}{*}{ Crop produced } & \multicolumn{3}{|c|}{ Quantity produced (bags*) } & \multicolumn{3}{|c|}{ Quantity stored (bags*) } \\
\hline & & $0-5$ & 6-10 & $>10$ & $0-5$ & 6-10 & $>10$ \\
\hline Maize** & 98.0 & 35.4 & 27.9 & 36.7 & 60.0 & 23.5 & 16.5 \\
\hline Beans & 66.7 & 85.5 & 10.3 & 4.3 & 93.5 & 4.3 & 2.2 \\
\hline Pigeon pea & 28.4 & 97.4 & 1.6 & 1.0 & 98.5 & 1.2 & 0.3 \\
\hline
\end{tabular}

Note. *Each bag has the capacity to store $90 \mathrm{~kg}$ of grain. ${ }^{* *}$ All data in the table are expressed as percent respondents.

Table 5. Grain storage practices - duration of storage, method of grain protection and location of storage — by farmers in three counties in Eastern Kenya

\begin{tabular}{ll}
\hline Variable & \% Respondents \\
\hline Duration of storage & 6.7 \\
Less than 3 months & 19.1 \\
3-6 months & 25.8 \\
6-9 months & 48.1 \\
More than 9 months & \\
\hline Method of preservation & 4.4 \\
Do nothing & 32.8 \\
Chemical pesticides & 0.8 \\
Natural products & 61.0 \\
Hermetic technologies & 0.5 \\
Others & \\
\hline Location of storage & 55.6 \\
Room in house & 13.9 \\
Farm store & 25.3 \\
Improved granaries & 12.4 \\
Traditional granaries & \\
\hline
\end{tabular}


Table 6. Grain storage practices_challenges during storage, methods of dealing with storage challenges, and reasons for not using chemicals - by farmers in three counties in Eastern Kenya

\begin{tabular}{ll}
\hline Variable & \% Respondents \\
\hline Challenges during storage & 56.8 \\
Insect damage & 43.1 \\
Rodent damage & 17.8 \\
Ineffective insecticides & 7.2 \\
Decay/mold & 2.6 \\
Theft & 46.3 \\
Method of dealing with storage challenges & 38.5 \\
Use new technologies & 14.0 \\
Apply chemicals & 17.6 \\
Feed livestock & 11.9 \\
Sell at harvest & \\
Consume & 9.6 \\
Reasons for not using chemicals & 2.9 \\
No insect attacks & 9.0 \\
Expensive & 11.4 \\
Not effective & 16.9 \\
Toxic & 50.2 \\
Others & \\
Don't use chemicals &
\end{tabular}

Table 7. Percent of farmers who saved seed and quantity of seed saved in three counties in Eastern Kenya

\begin{tabular}{llll}
\hline \multirow{2}{*}{ Variable } & \multicolumn{3}{c}{ \% Respondents } \\
\cline { 2 - 4 } & Beans & Pigeon pea & Maize \\
\hline Farmers who saved seed & 80 & 50 & 20 \\
Quantity saved by farmers & & & \\
Less than $10 \mathrm{~kg}$ & 64 & 80 & 92 \\
$10-30 \mathrm{~kg}$ & 21 & 12 & 5 \\
More than $30 \mathrm{~kg}$ & 15 & 8.5 & 3.2 \\
\hline
\end{tabular}

\section{Discussion}

\subsection{Characteristics of the Respondents}

About half of the farmers were an aging demographic, above 50 years. Older farmers are usually viewed least productive because most field work require physical effort. In addition, this may be a hindrance to adoption of new technologies which has a negative impact on food security. This is a universal trend caused by youth migration to urban centers among other factors. Policy-makers need to develop programs that incentivize the youth to be involved in agriculture. The average household size was five members which is similar to the Kenyan national average of between 4.9 to 5.7 people (Munene, 2003). Bigger households mean more family-labor and more incentives to produce more grain and store more for family consumption. The respondents had farming experience and had attained at least high school education which may positively influences their ability to make sound postharvest management decisions. It was apparent during the study that women played an important role in postharvest management in Eastern Kenya. Similar findings have been reported in West and Central Africa (Ibro et al., 2014; Moussa et al., 2014).

\subsection{Main Cereal and Legume Crops Cultivated}

The three major crops grown across the three counties were maize, beans and pigeon pea. Most farmers grew at least two major crops including a cereal and a legume. This agrees with the report that farmers in semi-arid areas of eastern Kenya grow two major and one minor grain crops (Wambugu \& Muthamia, 2009). Farmers cultivated cereals and legumes for food, feed and sale. Almost all farmers grew maize and most of it was hybrid-maize. Most farmers who grew maize sourced their seed from agrodealers as they saved little of their harvested grain. We think that the saved maize seeds are local varieties that are grown by farmers for family use or niche markets. The adoption of hybrid maize in Kenya has been increasing over the last few years and is high compared to other 
countries in the region (Schroeder et al., 2013). This is in part due to efforts by seed companies to produce hybrids that are adapted to local weather such as the semi-arid conditions. Studies have shown low hybrid seed adoption rates are common across developing economies worldwide, especially in Sub-Saharan Africa where it is approximately 40 percent (Smale et al., 2011). In contrast to maize, farmers saved their own legume seeds for replanting the next season. Saved legume seeds can still provide good yield if proper selection of planting material is done, since they are self-pollinating. Providing farmers with relevant information and knowledge about seed sourcing (whether saved or purchased) is critical as it affects their production. Planting good seed ensures good production.

\subsection{Drying and Storage Practices}

There was little variation in postharvest practices among the three study sites. Ideally, rainfall in these regions is bimodal with the long rains occurring from March to May and short rains from October to December. However, all these counties have been experiencing an overall decrease in precipitation and increase in temperatures, with negative impact on crop yields (Ojwang' et al., 2010; Gichangi et al., 2015). Farmers had several challenges during preharvest, the major ones being field infestations by insect, birds and rodents. There are limited solutions to deal with these preharvest issues. This may explain why fewer farmers were pre-drying their crops in the field. Drying has always been a challenge among smallholder farmers. This is often the case in areas where there are bimodal rainfalls such as Eastern Kenya. Sometimes the harvest season for one crop overlaps with the next planting, which is usually dictated by rainfall. This creates drying challenges for the mature crop to be harvested. Rain as a major challenge during drying was mentioned by more than half of respondents. Technologies are being developed to address drying challenges including the EasyDry M500 which is a mobile portable maize dryer targeted at servicing smallholder farmers (Walker \& Davies, 2017). With two thirds of farmers drying their crops on the ground, this may explain the high level of aflatoxin contamination in Kenya (Mwihia et al., 2008). The introduction of proper technologies will address issues of drying grain during rainy season including mold development and aflatoxin accumulation.

Farmers had a good understanding of storage and its implications for food security. Studies have shown the importance of storage in enhancing food security in semi-arid areas (Nduku et al., 2013). Regardless of quantity produced, majority of farmers stored at least two bags for home consumption. Smallholder farmers who owned less than two acres of land, especially in Tharaka-Nithi county, stored grain for home consumption. Though land sizes were a bit larger in Machakos and Makueni counties, adverse effect of changing weather patterns reduced their productivity. About four-fifths of the respondents stored their grain for more than 6 months. Similar trends have been observed in Tanzania where farmers stored for six or more months to secure food and get higher prices for their grain. Farmers need to store for at least six months to achieve the highest prices due to price seasonality of grain in African markets (Jones et al., 2011). Some farmers even stored for 12 months or longer. The main reason for longer storage was to build a buffer stock due to unpredictable weather patterns that may result in poor harvest in the following seasons. During the study, we even found some farmers who were storing cereal and legume grains for 24 and 36 months. Long storage was made possible with access to better storage technologies such as hermetic bags including the Purdue Improved Crop Storage (PICS), GrainPro, and AgroZ bags (Foy \& Wafula, 2016). Thanks to several efforts to reduce postharvest losses, these hermetic bags have been promoted in several counties by the Kenya Agriculture Value Chains (KAVES) Program and other projects (Nash et al., 2017). Cereal and legume crops can be stored or preserved for a very long time without major pre-processing (Appert, 1987). Better storage also helps preserve seed and avert agents of qualitative and quantitative grain loss like insects, rodents and mycotoxins (Adetunji, 2007). Qualitative loss through aflatoxin contamination of maize has been widely reported in Kenya, and especially in Machakos and Makueni counties (Kang'ethe, 2011; Maina et al., 2016). With hermetic bags, damage by pests and contamination by aflatoxins are mitigated (Njoroge et al., 2014; Maina et al., 2016; Williams et al., 2014).

\subsection{Storage Challenges}

The major challenges during storage were insects and rodents. Farmers reported using new storage technologies and insecticides to deal with these pest challenges. Farmers have relied on pesticides for grain preservation, but they have been shifting towards hermetic storage in recent years. Concerns with pesticides stem from food poisoning due to overuse and misuse of insecticides as well as their ineffectiveness linked to insect resistance (Nicolopoulou-Stamati et al., 2016). The availability of cost-effective storage options has increased farmers' willingness to invest in safe storage technologies. The introduction of various hermetic technologies in Kenya since 2013 followed by aggressive marketing and advertising has helped increase the adoption of these technologies. Studies have shown that hermetic storage for 6 months is more profitable than the use of chemicals (Foy \& Wafula, 2016). A study implemented in Uganda showed an increase in farmers' willingness to invest in 
hybrid maize varieties after accessing better storage technologies (Omotilewa et al., 2018). Farmers who had used hermetic bags for two years were 10 percent more likely to plant hybrid maize (high yielding but more susceptible to insect during storage) the following season compared to those who were using other storage methods.

Overall, farmers have a greater understanding of postharvest practices in the three counties in Eastern Kenya. Maize and common beans are the most important crops grown by farmers in these areas. Postharvest challenges linked to drying and storage such as aflatoxins and insects are serious challenges. Farmers are increasingly accessing new technologies and solutions to deal with these issues. Maize being such a staple crop grown by all farmers, there is a need to improve and promote pre-harvest and postharvest management practices to increase the use of new technologies such as improved seed, dryers, and hermetic storages devices.

\section{Acknowledgements}

We thank the PICS3 project (Grant number OPP1038622) funded by the Bill and Melinda Gates Foundation for facilitating this study. We also thank the individual farmers for their time and cooperation in participating in the survey. We wish to thank Willy Bett and Chris Miyinzi for technical support and all enumerators who made the data collection possible.

\section{References}

Abate, T., Alene, A. D., Bergvinson, D., Shiferaw, B., Silim, S., Orr, A., \& Asfaw, S. (2012). Tropical grain legumes in Africa and south Asia: Knowledge and opportunities. International Crops Research Institute for the Semi-Arid Tropics. Retrieved from http://oar.icrisat.org/5680/1/TLL-II_Feb_2012.pdf

Adetunji, M. O. (2007). Economics of Maize Storage Techniques by Fanners in Kwara State, Nigeria. Pakistan Journal of Social Sciences, 4(3), 442-45. https://doi.org/10.1080/10454440802537280

Appert, J. (1987). The storage of food grains and seeds. The Tropical Agriculturist, Macmillan, London. Retrieved from https://www.cabdirect.org/cabdirect/abstract/19886768321

County, T. N., Mucioki, K. M., Johns, T., \& Mucioki, S. K. (2016). Gendered food-and seed-producing traditions for pearl millet (Pennisetum glaucum) and sorghum (Sorghum bicolor) in Tharaka-Nithi County, Kenya. In Food Security, Gender and Resilience. Routledge. Retrieved from https://www.taylorfrancis.com/bo oks/e/9781317596585/chapters/10.4324\%2F9781315745855-7

FAO. (2014). Analysis of price incentives for Maize in Kenya. In W. M. Mulinge, N. M. Ng'ang'a, A. W. Mwaniki, F. M. Murithi, \& M. Ahmed (Eds.), Technical notes series, MAFAP. Rome. Retrieved from http://www.fao.org/fileadmin/templates/mafap/documents/technical_notes/KENYA/2005-2013/Kenya_TN_ Maize_web_review.pdf

FARA. (2006). Framework for African Agricultural Productivity/Cadre pour la productivité agricole en Afrique. Accra, Ghana, FARA. Retrieved from https://faraafrica.org/wp-content/uploads/2015/04/FAAP_English.pdf

Foy, C., \& Wafula, M. (2016). Scaling up of Hermetic Bag Technology (PICS) in Kenya: Review of successful scaling of agricultural technologies. United States Agency for International Development. Retrieved from https://www.agrilinks.org/sites/default/files/resource/files/BFS\%20Scaling\%20Review\%20-\%20Kenya\%20 Report\%20REVISED\%20508\%2011-16-16.pdf

Gichangi, E. M., Gatheru, M., Njiru, E. N., Mungube, E. O., Wambua, J. M., \& Wamuongo, J. W. (2015). Assessment of climate variability and change in semi-arid eastern Kenya. Climatic Change, 130(2), 287-297. https://doi.org/10.1007/s10584-015-1341-2

Gitonga, K. (2017). Grain and Feed Annual: 2017 Kenya Corn, Wheat and Rice Report. GAIN Report. Retrieved from https://gain.fas.usda.gov/Recent\%20GAIN\%20Publications/Grain\%20and\%20Feed\%20Annual_Nairo bi_Kenya_3-21-2017.pdf

Gitonga, Z. M., De Groote, H., Kassie, M., \& Tefera, T. (2013). Impact of metal silos on households' maize storage, storage losses and food security: An application of a propensity score matching. Food Policy, 43, 44-55. https://doi.org/10.1016/j.foodpol.2013.08.005

IBM Corp. (2016). IBM SPSS Statistics for Windows, Version 24.0. Armonk, NY: IBM Corp.

Ibro, G., Sorgho, M. C., Idris, A. A., Moussa, B., Baributsa, D., \& Lowenberg-DeBoer, J. (2014). Adoption of cowpea hermetic storage by women in Nigeria, Niger and Burkina Faso. Journal of Stored Products Research, 58, 87-96. https://doi.org/10.1016/j.jspr.2014.02.007 
Jaetzold, R., Schmidt, H., Hornet, Z. B., \& Shisanya, C. A. (2006). Farm management handbook of Kenya. Vol. II: Natural conditions and farm management information (2nd ed., Part II/C: East Kenya, Subpart C1: Eastern Province). Nairobi: Ministry of Agriculture, Kenya. Retrieved from http://www2.giz.de/dokumen te/bib/07-1282.pdf

Jones, M., Alexander, C., \& Lowenberg-DeBoer, J. (2011). Profitability of hermetic Purdue Improved Crop Storage (PICS) bags for African common bean producers (pp. 1-29). Department of Agricultural Economics, Purdue University, USA. Retrieved from https://www.researchgate.net/profile/Michael_Jones48/publicati on/270568904_Profitability_of_Hermetic_Purdue_Improved_Crop_Storage_PICS_Bags_for_African_Com mon_Bean_Producers/links/54ad6e190cf2828b29fc9508/Profitability-of-Hermetic-Purdue-Improved-CropStorage-PICS-Bags-for-African-Common-Bean-Producers.pdf

Kang'ethe, E. (2011). Situation analysis: Improving food safety in the maize value chain in Kenya. Report prepared for FAO. College of Agriculture and Veterinary Science, University of Nairobi, Nairobi. Retrieved from http://www.fao.org/fileadmin/user_upload/agns/pdf/WORKING_PAPER_AFLATOXIN_REPORTDJ 10thOctober.pdf

Kimiti, J. M., Odee, D. W., \& Vanlauwe, B. (2009). Area under grain legumes cultivation and problems faced by smallholder farmers in legume production in the semi-arid eastern Kenya. Journal of Sustainable Development in Africa, 11(4), 305-315.

Macauley, H., \& Ramadjita, T. (2015). Cereal crops: Rice, maize, millet, sorghum, wheat. Feeding Africa, 36.

Maina, A. W., Wagacha, J. M., Mwaura, F. B., Muthomi, J. W., \& Woloshuk, C. P. (2016). Postharvest practices of maize farmers in Kaiti District, Kenya and the impact of hermetic storage on populations of Aspergillus spp. and aflatoxin contamination. Journal of Food Research, 5(6), 53. https://doi.org/10.5539/jfr.v5n6p53

Mergeai, G., Kimani, P., Mwang'ombe, A., Olubayo, F., Smith, C., Audi, P., Baudoin, J. P., \& Le Roi, A. (2001). Survey of pigeonpea production systems, utilization and marketing in semi-arid lands of Kenya. Biotechnologie, Agronomie, Société et Environnement, 5(3), 145-153.

Moussa, B., Abdoulaye, T., Coulibaly, O., Baributsa, D., \& Lowenberg-DeBoer, J. (2014). Adoption of on-farm hermetic storage for cowpea in West and Central Africa in 2012. Journal of Stored Products Research, 58, 77-86. https://doi.org/10.1016/j.jspr.2014.02.008

Muhammad, L., Mwabu, D., Mulwa, R., Mwangi, W. M., Langyintuo, A. S., \& La Rovere, R. (2010). Characterization of maize producing households in Machakos and Makueni Districts in Kenya. KARI-CIMMYT Publication produced as part of the Drought Tolerant Maize for Africa (DTMA) Project. Retrieved from http://dtma.cimmyt.org/index.php/publications/doc_view/120-kenya-household-survey-2010

Munene, F. M. (2003). Household Population and Housing Characteristics. Kenya Demographic and Health Survey. Nairobi, Kenya Central Bureau of Statistics. Retrieved from https://dhsprogram.com/pubs/pdf/ FR151/00FrontMatter.pdf

Mutambuki, K., \& Ngatia, C. (2006). Loss assessment of on-farm stored maize in semi-arid area of Kitui District, Kenya. Proceedings of the 9th International working conference on stored product protection (PS1-1-6318) held on 15-18 October. Retrieved from http://spiru.cgahr.ksu.edu/proj/iwcspp/pdf2/9/6318.pdf

Mwihia, J. T., Straetmans, M., Ibrahim, A., Njau, J., Muhenje, O., Guracha, A., ... Breiman, R. F. (2008). Aflatoxin levels in locally grown maize from Makueni District, Kenya. East African Medical Journal, 85(7), 311-317. https://doi.org/10.4314/eamj.v85i7.9648

Nash, J., Peña, O., Galford, G., Gurwick, N., Pirolli, G., White, J., \& Wollenberg, E. (2017). Reducing food loss in agricultural development projects through value chain efficiency. CCAFS Working Paper No. 204. Retrieved from https://ccafs.cgiar.org/publications/reducing-food-loss-agricultural-development-projects-thr ough-value-chain-efficiency\#.W84afvZRdpk

Nduku, T. M., De Groote, H., \& Nzuma, J. M. (2013). Comparative analysis of maize storage structures in Kenya. 4th Conference of the African Association of Agricultural Economists (AAAE). Retrieved from https://pdfs.semanticscholar.org/4097/4684765e2cbedf51180c96466c873d4718ec.pdf

Nicolopoulou-Stamati, P., Maipas, S., Kotampasi, C., Stamatis, P., \& Hens, L. (2016). Chemical pesticides and human health: The urgent need for a new concept in agriculture. Frontiers in Public Health, 4, 148. https://doi.org/10.3389/fpubh.2016.00148 
Njoroge, A. W., Affognon, H. D., Mutungi, C. M., Manono, J., Lamuka, P. O., \& Murdock, L. L. (2014). Triple bag hermetic storage delivers a lethal punch to Prostephanus truncatus (Horn) (Coleoptera: Bostrichidae) in stored maize. Journal of Stored Products Research, 58, 12-19. https://doi.org/10.1016/j.jspr.2014.02.005

Ojwang, G. O., Agatsiva, J., \& Situma, C. (2010). Analysis of climate change and variability risks in the smallholder sector. FAO. Retrieved from http://www.fao.org/docrep/013/i1785e/i1785e00.pdf

Omotilewa, O. J., Ricker-Gilbert, J., Ainembabazi, J. H., \& Shively, G. E. (2018). Does improved storage technology promote modern input use and food security? Evidence from a randomized trial in Uganda. Journal of Development Economics, 135, 176-198. https://doi.org/10.1016/j.jdeveco.2018.07.006

Rao, E. J. O., Midega, C., Atieno, F., Auma, J. O., Cadilhon, J. J., Mango, N., ... Wesonga, M. (2015). A situational analysis of agricultural production and marketing, and natural resources management systems in West Kenya. Retrieved from https://cgspace.cgiar.org/handle/10568/71084

Schroeder, C., Onyango, T. K. O., Nar, R. B., Jick, N. A., Parzies, H. K., \& Gemenet, D. C. (2013). Potentials of hybrid maize varieties for small-holder farmers in Kenya: A review based on Swot analysis. African Journal of Food, Agriculture, Nutrition and Development, 13(2). http://www.bioline.org.br/pdf?nd13033

Smale, M., Byerlee, D., \& Jayne, T. (2011). Maize revolutions in Sub-Saharan Africa. The WorldBank. Retrieved from https://ageconsearch.umn.edu/bitstream/202592/2/Wp40-Maize-Revolutions-in-sub-Saharan-Africa.pdf

Speranza, C. I., Kiteme, B., \& Wiesmann, U. (2008). Droughts and famines: The underlying factors and the causal links among agro-pastoral households in semi-arid Makueni district, Kenya. Global Environmental Change, 18(1), 220-233. https://doi.org/10.1016/j.gloenvcha.2007.05.001

Stathers, T., Lamboll, R., \& Mvumi, B. M. (2013). Postharvest agriculture in changing climates: Its importance to African smallholder farmers. Food Security, 5(3), 361-392. https://doi.org/10.1007/s12571-013-0262-z

Tabu, J. S., Otwelo, J. A., Koskei, P., \& Makokha, P. (2013). Hazard Analysis of Arid and Semi-Arid (ASAL) Regions of Kenya. East African Journal of Public Health, 10(2), 411-416.

Van Duivenbooden, N., Pala, M., Studer, C., Bielders, C. L., \& Beukes, D. J. (2000). Cropping systems and crop complementarity in dryland agriculture to increase soil water use efficiency: A review. NJAS-Wageningen Journal of Life Sciences, 48(3), 213-236. https://doi.org/10.1016/s1573-5214(00)80015-9

Walker, S., \& Davies, B. (2017). Feasibility of Up-scaling the EasyDry M500 Portable Maize Dryer to Kenya. USAID and Bill and Melinda Gates Foundation. Retrieved from http://www.acdivoca.org/wp-content/uploa ds/2017/06/EasyDry-M500-Analysis-of-Commercialization-Viability.pdf

Wambugu, P. W., \& Muthamia, Z. K. (2009). The State of Plant Genetic Resources for Food and Agriculture in Kenia. Submitted to FAO Commission on Plant Genetic Resources for Food and Agriculture. Retrieved from http://www.fao.org/pgrfa-gpa-archive/ken/kenya2.pdf

Wiggins, S., \& Keats, S. (2013). Leaping and learning: linking smallholders to markets in Africa. Agriculture for Impact, Imperial College and Overseas Development Institute, London. Retrieved from https://www.odi.org/ sites/odi.org.uk/files/odi-assets/publications-opinion-files/8401.pdf

Williams, S. B., Baributsa, D., \& Woloshuk, C. (2014). Assessing Purdue Improved Crop Storage (PICS) bags to mitigate fungal growth and aflatoxin contamination. Journal of Stored Products Research, 59, 190-196. https://doi.org/10.1016/j.jspr.2014.08.003

\section{Copyrights}

Copyright for this article is retained by the author(s), with first publication rights granted to the journal.

This is an open-access article distributed under the terms and conditions of the Creative Commons Attribution license (http://creativecommons.org/licenses/by/4.0/). 